\title{
Moderate-to-vigorous physical activity during recess and physical education among mexican elementary school students \\ Actividad física moderada a vigorosa durante el recreo y clase de educación física en niños mexicanos de escuela primaria \author{
Sáenz-López Buñuel \\ *Universidad Autónoma de Baja California (México), *Universidad Autónoma de Sinaloa (México), ${ }^{* * * U n i v e r s i d a d ~ d e ~ H u e l v a ~(E s p a n ̃ a) ~}$
} \\ *Javier Arturo Hall-López, *Paulina Yesica Ochoa-Martínez, *Rodrigo Zuñiga Burruel, **Luis Roberto Monreal Ortiz, , ***Pedro
}

\begin{abstract}
Objective: To compare the moderate-to-vigorous physical activity of physical education classes taught by teachers and their students during recess. Method: In order to determine the physical activity intensity the system for observing fitness instruction time (SOFIT) was used, a descriptive cross-sectional comparative methodological design was used, 63 physical education classes were evaluated selecting randomly four students from each class ( 2 men and 2 women), the same procedure was followed to evaluate the same 4 students during the 30 minutes of recess. Results: The equality of variance was calculated using the Student t test for independent samples resulting a P-value=.001 ád» less than 0.05 , with a percentage time of moderateto-vigorous physical activity in physical education classes taught by teachers of $41 \% \pm 17.7$ and performed by students during recess of $50 \% \pm 10.3$, the percentage of difference (Ä\%) was of $18 \%$ between the variables. Conclusion: The intensity of physical activity during recess was higher without teacher instruction in relation to physical education classes evaluated, due is important a feedback for the teachers in strategies for involving the students in moderate to vigorous physical activity as established by the World Health Organization.
\end{abstract}

Keywords: physical education, recess, elementary education, physical activity, teachers.

Resumen. Objetivo: Comparar la actividad física moderada a vigorosa de clases de educación física impartidas por profesores y la intensidad de la actividad física de sus estudiantes durante el recreo. Método: Se utilizó como instrumento de evaluación el sistema para observar el tiempo de instrucción de actividad física (SOFIT), el diseño metodológico fue transversal descriptivo comparativo, evaluando 63 clases de educación física seleccionado al azar cuatro estudiantes de cada clase (2 hombres y 2 mujeres), el mismo procedimiento se siguió, evaluando a los mismos 4 estudiantes durante los 30 minutos del recreo. Resultados: La igualdad de la varianza se calculó mediante la prueba t Student para muestras independientes resultando una P-Valor=.001 menor a ád» 0.05 , el porcentaje de tiempo de actividad física moderada a vigorosa en las clases de educación física impartidas por profesores fue de $41 \% \pm 17.7$ y la realizada por los estudiantes durante el recreo resulto en $50 \% \pm 10.3$ y un porcentaje de diferencia (Ä\%) de $18 \%$. Conclusión: La intensidad de actividad física durante el recreo fue mayor sin instrucción docente en relación a las clases de educación física evaluadas, por lo anterior es importante retroalimentar de manera constructiva la manera de impartir la clase de los profesores mediante capacitación con estrategias didácticas para involucrar al alumno en actividad física moderada a vigorosa como lo establece la Organización Mundial de la Salud.

Palabras clave: educación física, recreo, educación primaria, actividad física, profesores.

\section{Introduction}

There is scientific evidence pointing than sedentary lifestyle in children is associated with several chronic diseases including metabolic syndrome(Shilton, 2008, Broyles etal., 2010). Research studies suggest that time engaged in regular moderate-to-vigorous physical activity during childhood is a contributing factor to become a physically active as adult (Kim, 2012, Ali et al., 2014). In schools, physical education lesson has been highlighted as the place to reach most young people to promote a healthy active lifestyle (Lonsdale et al., 2013, Rivera-Sosa \& Arras-Vota, 2015, Langford et al., 2015).

According with the Mexican National Survey of Health and Nutrition 2012, 58.6\% children among 10 to 14 year old are not physically active after school in a formal program, whereas the combined prevalence of overweight and obesity in school children was 34.4\% (ENSANUT, 2012). The world wide of health (WHO) recommend for children achieving at least 60 minutes or more of daily moderate-tovigorous physical activity in order to improve a healthy growth and development (WHO, 2016).

In Mexico, the Secretariat of Public Education (SEP for its abbreviation in Spanish) establish than elementary school curriculum offers physical education whose primary goals include developing motor skills and teaching about the importance of leading an active lifestyle and the difference with others subjects as sciences, mathematics, civics, is than is the only formal program where children can experience moderate-to-vigorous physical activity (SEP, 2008, SEP, 2008). In addition, in the elementary Mexican schools the recess is a mandatory 30-minute period in which students have the opportunity to eat and be physically active(SEP, 2014). Unfortunately, a recent research conducted in Mexico identified than more than $90 \%$ of the recess period was spent at light or sedentary physical activity (Medina et al., 2015), moreover

Fecha recepción: 22-04-16. Fecha de aceptación: 15-08-16 Paulina Yesica Ochoa-Martínez

pochoa@uabc.edu.mx direct observation assessing physical activity using the system for observing fitness instruction time showed in two samples of Mexican elementary school physical education classes only accrued an average of $38.2 \%$ and $29.2 \%$ of moderate-to-vigorous physical activity in class time (Jennings-Aburto et al., 2009, Pérez Bonilla, 2009), these results partial contradict other findings than showed $54 \%$ of moderate-tovigorous physical activity in class time (Gharib et al., 2015).

During school time the intensity of physical activity can be influenced by the context as, teacher credentials, class size, equipment, facilities, scheduled lesson length and the number of lessons provided per week (Smith, Lounsbery, \& McKenzie, 2014, Salazar et al., 2015, Sutherland et al., 2016, Honório et al., 2016), In this context, In Mexico, there is a lack of studies describing the physical activity among school children's; Therefore, this study was designed to compare the moderate and vigorous physical activity during recess and physical education among 4th, 5th and 6th grade Mexican elementary school students.

\section{Methods}

\section{Participants and setting}

The present study follows a cross-sectional methodological design, with a non-probabilistic convenience sample, in total the study sample was based on 23 public elementary schools located in the urban area of Mexicali Baja California in Mexico, classified as low socioeconomic status, morning sessions, the schools were required to possess a minimum of facilities to conduct the physical education lessons, population above 500 students at least two groups of fourth, fifth and sixth grade students.

The study followed the ethical principles regarding human experimentation proposed by the Helsinki declaration (Puri, Suresh, Gogtay, \& Thatte, 2009); and was approved by the research program of the Faculty of Sports of the Autonomous University of Baja California.

\section{Measures and procedures}

In order to quantify the physical activity during the physical education classes and recess, the System for Observing Fitness 
Instruction Time (SOFIT) was used, SOFIT is an objective tool for assessing the quality of physical education instruction that provides a measure of student activity levels and has been calibrated using heart rate monitors and validated using accelerometers (Mckenzie, Sallis, \& Nader, 1992, McKenzie, 2002). For the current study, tow data collectors were trained following the standard of SOFIT protocol, memorizing operational definitions of codes and learning the tactical procedures and reliability measures were taken in $100 \%$ of the observations (Kappa statistics .091).

Sixty-Three physical education classes were evaluated, attended by fourth, fifth and sixth grade students of elementary school (Mean age $=10,6 \pm 0,2$ years), four students were randomly select ( 2 girls and 2 boys) based on the order in which they arrived at the class, using the procedures outline in the SOFIT manual, in summary observers record intensity of physical activity using a time-sampling system of 10seconsd observe and 10 -seconds records intervals while being paced by audio prompts from a mp3 player. The coded intensity of physical activity was scored as $1=$ =lying down; $2=$ sitting; $3=$ =standing; $4=$ =walking; $5=$ very active. To identify moderate-to-vigorous physical activity the codes $4=$ walking and $5=$ very active were combined as the proportion of time than students are engaged in these codes.

The lesson context in physical education classes were identify as $\mathrm{M}=$ management; $\mathrm{K}=$ general knowledge; $\mathrm{P}=$ physical fitness knowledge; $\mathrm{F}=$ fitness activity; $\mathrm{S}=$ =skill drills; $\mathrm{G}=$ game play; $\mathrm{O}=$ Other (e.g., free play).

The four same physical education students were observed during the 30 minutes recess period, the observers move around the school facilities in order to code the intensity of physical activity in order to assess the moderate-to-vigorous physical activity quantified as the proportion of time than students engaged in walking and very active physical activity during recess period.

\section{Analysis}

Statistical analyses were performed using statistical software SPSS for Windows version 21 (IBM Corporation, New York, USA). Descriptive statistical procedures are presented as mean \pm standard deviation and range; $t$ Student test for independent samples was computed to determinesignificantmean differences between themoderate to vigorous physical activity index of physical education and recess groups. Statistical significance test was set a priori at $p<0.05$. Also percentage of difference $(\Delta \%)$ was calculated for moderate to vigorous physical activity index of physical education classes taught by teachers and their students during recess (Thomas et al., 2001).

\section{Results}

There were 63 physical education classes conducted by teachers, 50 male (38.6 \pm 9.3 year old) and 13 female ( $34.2 \pm 6.3$ year old), the mean of years of experience as permanent physical education specialist were 13.8 \pm 9.1 in male and $8.9 \pm 5.5$ in female. Within the schools the physical education classes observed representing 1,765 children (51\% girls and $49 \%$ boys) enrolled in 4th grade $(n=19,30.1 \%)$ th grade $(n=23,36.5 \%)$ and 6th grade $(n=21,33.4 \%)$, both activities were held outdoors with an average duration of 39,0 06,7 minutes for physical education classes and 29,9 $\pm 1,2$ for the recess period, descriptive characteristics are presented in table 1.

Table 1.

Descriptive statistics for the sample $(n=63)$.

\begin{tabular}{lcccccccccc}
\hline & \multicolumn{4}{c}{ Physical Education Classes } & \multicolumn{4}{c}{ Recess Period } \\
\cline { 2 - 10 } \multicolumn{1}{c}{ Variables } & M & SD & \% Time & Range & M & SD & \%Time & Range \\
\hline 1) Lying Down (min) & 0.3 & \pm & 0.7 & 0.8 & $0-3$ & 1 & \pm & 1.2 & 3.2 & $0-5$ \\
2) Sitting (min) & 3.8 & \pm & 5.1 & 10 & $0-29.4$ & 8 & \pm & 3.4 & 26.6 & $0-17$ \\
3) Standing (min) & 18.7 & \pm & 7.8 & 19.7 & $6.4-37$ & 5.9 & \pm & 2.5 & 19.7 & $1-12.6$ \\
4) Walking (min) & 11.5 & \pm & 6.5 & 28.8 & $1-29.3$ & 9.6 & \pm & 2.4 & 31.9 & $3-15$ \\
5) Very Active (min) & 4.8 & \pm & 3.1 & 12 & $0-13$ & 13 & \pm & 2 & 18.2 & $1.2-12$ \\
\hline
\end{tabular}

The greatest proportion of lesson context in physical education classes was game play (mean $=34 \%$ ), followed by management $(23 \%)$ and fitness activity (21\%), skill drills and other (e.g., free play) were spent by $9 \%$ and $7 \%$ respectively, meanwhile little proportion lesson time was allocated to general knowledge (3\%) and physical fitness knowledge (2\%). Due during recess there was not fitness instruction, the context was $100 \%$ other (e.g., free play).

The percentage of difference $(\Delta \%)$ of moderate-to-vigorous physical activity (combined codes $4=$ walking and $5=$ =very), was of $18 \%$ more in recess than physical education classes. Figure 1 . Provides the data of the t-test for independent samples resulting a P-value $=.001<0.05$, significance differences were observed with more percentage time of moderate-to-vigorous physical activity than students remained in recess (mean percentage time $50 \pm 10.3$ ) than in physical education classes (mean percentage time $=41 \pm 17.7$ ).

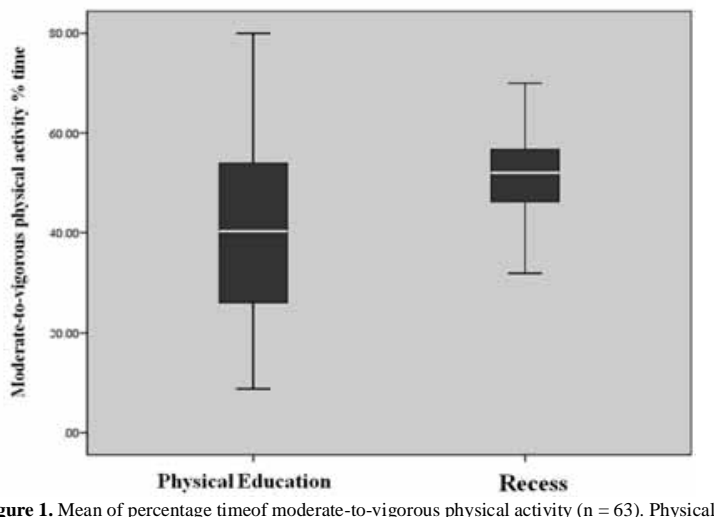

Figure 1. Mean of percentage timeof moderate-to-vigorous physical activity $(\mathrm{n}=63)$. Physical education classes (mean percentage time $=41 \pm 17.7$ ) recess (mean percentage time $50 \pm 10.3$ ); Pvalue $=.001<0.05$.

\section{Discussion}

The main findings reveal important data related to differences in physical activity during school time, the time engaged of moderate-tovigorous physical activity during recess was higher than physical education classes among a sample of children enrolled in Mexican public elementary schools. According with the National Association for Sport and Physical Education (NASPE) as strategies to improve the quality of physical education recommends that students engage in moderateto-vigorous physical activity for at least $50 \%$ of the time of the class in order to provides numerous physiological and psychosocial benefits of physical activity (NASPE, 2009, Banville, 2006), the results of our data do not reach this international recommendations for physical education, these findings are corroborated with research of Mexican elementary schools where reported an average of moderate-to-vigorous physical activity in class time of 38.2\% and 29.2\% (Jennings-Aburto et al., 2009, Pérez Bonilla, 2009), this suggest than teachers behavior and lesson context of the Mexican physical education curriculum do not promote to achieve international recommendations. Regarding the assessment of lesson context with the System for Observing Fitness Instruction Time (SOFIT), this study was consistent with other made in Mexico (Gharib et al., 2015).

The physical activity during the recess time was not organized, without teaching instructions and students participate (50.1\%) in more moderate-to-vigorous physical activity than in physical education class (40.8\%) it was consistent with other cross-sectional study than report $39.6 \%$ of moderate-to-vigorous physical activity during the recess period and 29.2\% during the physical education class (Jennings-Aburto et al., 2009). Previous studies than evaluate the moderate-to-vigorous physical activity during the recess period in schools reports $66.4 \%$ (Medina et al., 2015) and 33.7\% (Springer, Tanguturi, Ranjit, Skala, \& Kelder, 2013), there are many factors that determine the intensity of physical activity during school time including teacher credentials, class size, equipment, facilities, scheduled lesson length and the number of lessons provided per week (Hernández-Álvarez et al., 2010, Skala, Springer, Sharma, Hoelscher, \& Kelder, 2012, Mckenzie et al., 2015, Navas \& Soriano, 2016). Systematic review and meta-analysis suggests that children and adolescents than engage in regular physical activity are 
associated with lower risk of chronic diseases as obesity (Brooke et al., 2014; Sims et al., 2015); The World Health Organization (WHO) recommends that children aged 5-17 years should accumulate at least 60 minutes of moderate- to vigorous-intensity physical activity daily (WHO, 2016). In schools, physical education lesson has been highlighted as the place to reach most young people to promote a healthy active lifestyle (Kim, 2012, López-Alonzo et al., 2015, Langford et al., 2015; Lonsdale et al., 2013). The present study is limited by the sample size of Physical Education teachers who conduct a curriculum in a pedagogical model of competencies and delimited to Mexican school context, in addition this cross-sectional study prevents us from inferring causality. Despite of these limitations, the results presented here allow us to better understand potential limitations when the physical education classes did not reach the international standards of have a moderate-tovigorous intensity above $50 \%$ of class time, also the measure instruments used in the research is valid, easy to apply in large samples, it have a low cost and offer a non-invasive means to measure the intensity of physical activity in physical education or recess period as well as providing educational support for teachers within the context and teachers might find it useful to design proposals aimed at increasing the physical activity among children also contributes to the physical education knowledge regarding the physical activity recommendations as established by the World Health Organization. The topic seems relevant since inappropriate dietary habits and lack of physical activity are common in Mexican children. In summary, the intensity of physical activity during recess was higher without teacher instruction in relation to physical education classes evaluated, however, it will be appropriate in the future more studies to better clarify the strategies to enhance physical activity during the school period.

\section{References}

Ali, O., Cerjak, D., Kent, J.W., Jr., James, R., Blangero, J., \& Zhang, Y. (2014) Obesity, central adiposity and cardiometabolic risk factors in children and adolescents: a family-based study. Pediatr Obes, 9(3), e58-62. doi:10.1111/ j.2047-6310.2014.218.x

Banville, D. (2006). Analysis of exchanges between novice and cooperating teachers during internships using the NCATE/NASPE standards for teacher preparation in physical education as guidelines. Res Q Exerc Sport, 77(2), 208-221.

Broyles, S., Katzmarzyk, P.T., Srinivasan, S.R., Chen, W., Bouchard, C., Freedman, D.S., \& Berenson, G.S. (2010). The pediatric obesity epidemic continues unabated in Bogalusa, Louisiana. Pediatrics, 125(5), 900-905. doi:10.1542 peds.2009-2748

Encuesta Nacional de Salud y Nutrición 2012 ENSANUT2012 data revisited. (n.d.). Retrieved may 29, 2013, from the Instituto Nacional de Salud Publica; 2013. website, http://ensanut.insp.mx/

Gharib, H., Galaviz, K.I., Lee, R.E., Safdie, M., Tolentino, L., \& Barquera, S. (2015). The Influence of Physical Education Lesson Context and Teacher Behaviour on Student Physical Activity in Mexico Retos, 28:160-164.

Hernández-Álvarez, J.L., del-Campo-Vecino, J., Martínez-de-Haro, V., \& MoyaMorales, J.M. (2010). Perception of exertion in physical education and its relationship to guidelines on physical activity.RevInt Med Cienc Ac, 10(40),609619.

Honório, S., Martins, J., Torres, B., Cardoso, J., \& Costa, A. (2016). Influence of sociological aspects on the level of physical activity in physical education students. Journal of Human Sport \& Exercise, 10(3). doi:http://dx.doi.org/ 10.14198/jhse.2015.103.07

Jennings-Aburto, N., Nava, F., Bonvecchio, A., Safdie, M., Gonzalez-Casanova, I. Gust, T., \& Rivera, J. (2009). Physical activity during the school day in public primary schools in Mexico City. Salud Publica Mex, 51(2), 141-147

Kim, J. (2012). Are physical education-related state policies and schools' physical education requirement related to children's physical activity and obesity? JSch Health, 82(6), 268-276. doi:10.1111/j.1746-1561.2012.00697.x

Langford, R., Bonell, C, Jones, H., Pouliou, T., Murphy, S., Waters, E., Komro, K., Gibbs, L., Magnus, D., \& Campbell R. (2015). The World Health Organization's Health Promoting Schools framework: a Cochrane systematic review and meta-analysis. BMC Public Health, 12;15:130. doi: 10.1186/ s12889-015-1360-y.

Lonsdale, C., Rosenkranz., R.R., Peralta, L.R., Bennie, A., Fahey, P., \& Lubans, D.R. (2013). Asystematic review and meta-analysis of interventions designed to increase moderate-to-vigorous physical activity in school physical education lessons. Prev Med, 56(2):152-61. doi: 10.1016/j.ypmed.2012.12.004.
López-Alonzo, S.J., Marín-Uribe, R., \& Rivera Sosa, J.M. (2015). Percepción de la educación física en docentes universitarios. Educación Física y Ciencia, 17(1), $1-8$

McKenzie, T.L., van der Mars, H. (2015). Top 10 research questions related to assessing physical activity and its contexts using systematic observation. Res QExerc Sport, 86(1), 13-29. doi:10.1080/02701367.2015.991264

McKenzie TL. SOFIT. System for Observing Fitness Instruction Time. Overview and Training Manual. San Diego, CA: San Diego State University. 2002.

Mckenzie, T. L., Sallis, J. F., \& Nader, P. R. (1992). Sofit - System for Observing Fitness Instruction Time. J Teach Phys Educ 11(2), 195-205.

Medina C., Barquera S., Katzmarzyk PT., Janssen I. (2015). Physical activity during recess among 13-14 year old Mexican girls. BMC Pediatr, 15(17), 2-8. doi: 10.1186/s12887-015-0329-4.

Navas, L. \& Soriano, J.A. (2016). Análisis de los motivos para practicar o no actividades físicas extracurriculares y su relación con el autoconcepto físico en estudiantes chilenos. Revista Iberoamericana de Psicología del Ejercicioy el Deporte, 11(1) 69-76.

Puri, K.S., Suresh, K.R., Gogtay, N.J., \& Thatte, U.M. (2009). Declaration of Helsinki, 2008: implications for stakeholders in research. J Postgrad Med, 55(2), 131-134. doi:10.4103/0022-3859.52846

Pérez Bonilla,A. M.(2009). Impacto de la clase de educación física sobre la actividad moderada y vigorosa en niños de primaria. Rev Mex Cult Fis, 1(1),150-172.

Rivera-Sosa, J.M., \& Arras-Vota,A,M. (2015). Educación física y la «alfabetización física». (1st. Ed.). En Tarango, J., Mendoza Meraz, G., Fierro Ramírez, L. A., Baca, G. A. (Eds): Aproximaciones teórico-conceptuales y metodológicas en investigación educativa, Publisher: Universidad Autónoma de Chihuahua, pp.40-48.

Salazar, C.M., Gómez-Figueroa, J.A., Pérez, M.P., Vargas, C.S., Flores-Moreno, P.J., Medina-Valencia, R.T., Del Rio, J., \& Hernández-Murúa, J.A. (2015) Vocational Training and Basic Knowledge of the Mexican University Coach. Sociology Study, 5(3), 232-244. doi:10.17265/2159/5526/2015.03.007.

Secretaría de educación pública data revisited. (n.d.). Retrieved june 9, 2014, from the Lineamientos para la Organización y el Funcionamiento de las Escuelas de Tiempo Completo México; 2014. Population website, http:// basica.sep.gob.mx/seb2010/pdf/MCTE/3LiORFunETCEduPri.pdf

Secretaría de educación pública data revisited.(n.d.). Retrieved may 29, 2014, from the Plan de Estudios 2009 para Educación Básica. Primarias. Etapa de Prueba, México; 2009. Population website, http://efmexico.wordpress.com/apoyosdidacticos-para-la-clase-de-ef/programas-para-educacion-basica/

Shilton, T. (2008). Creating and making the case: global advocacy for physical activity. J Phys Act Health, 5(6), 765-776. Retrieved from http:// www.ncbi.nlm.nih.gov/pubmed/19164814

Skala, K.A., Springer, A.E., Sharma, S.V., Hoelscher, D.M., \& Kelder, S.H (2012). Environmental characteristics and student physical activity in PE class: findings from two large urban areas of Texas. JPhys Act Health, 9(4), 481-491. Retrieved from http://www.ncbi.nlm.nih.gov/pubmed/21934165

Smith, N.J., Lounsbery, M.A., \& McKenzie, T.L. (2014). Physical activity in high school physical education: impact of lesson context and class gender composition. JPhys Act Health, 11(1), 127-135. doi:10.1123/jpah.2011-0334

Springer, A.E., Tanguturi, Y., Ranjit, N., Skala, K.A., \& Kelder, S.H. (2013). Physical activity during recess in low-income third-grade Texas students. Am J Health Behav, 37(3), 318-324. doi:10.5993/AJHB.37.3.4

Subsecretaríadeeducación básica direccióngeneral dedesamollocurricular subdirección de educación física data revisited. (n.d.). Retrieved january 9, 2014, from the GuíadeEducación Física paralaEducación Primaria, México; 2008. Population website,http:/efmexico.files.wordpress.com/2008/08/guia_primarias_piloto.pdf

Sutherland, R., Campbell, E., Lubans, D. R., Morgan, P. J., Okely, A. D., Nathan, N., ... Wiggers, J. (2016). Physical education in secondary schools located in low-income communities: Physical activity levels, lesson context and teacher interaction. J Sci Med Sport, 19(2), 135-141. doi:10.1016/j.jsams.2014.12.003

Thomas, J.R., Nelson, J.K., Silverman, S., \& Silverman, S.J. (2001) Research Methods in Physical Activity (6th. Ed.). Champaign, Ilinois: Human Kinetics.

United States' National Association for Sport and Physical Education NASPE data revisited.(n.d.). Retrieved march 27, 2016, from thenational standards guidelines and position statements, E.U.A; 2009. Population website,http:// www.aahperd.org/naspe/.

World health Organization WHO data revisited. (n.d.). Retrieved january 9, 2016 from the Global Strategy on Diet, Physical Activity and Health, Physical Activity and Young People, Recommended levels of physical activity for children aged 5 - 17 years; http://www.who.int/dietphysicalactivity/ factsheet_young_people/en

World health Organization WHO data revisited. (n.d.). Retrieved january 9, 2016, from the Global Strategy on Diet, Physical Activity and Health, What is Moderate-intensity and Vigorous-intensity Physical Activity? Intensity of physical activity; http://www.who.int/dietphysicalactivity/physical_activity_intensity/ en/ 